\title{
Assessment of forest thinning intensity using sparse point clouds from repeated airborne lidar measurements
}

\author{
Mait Lang ${ }^{1,2^{*}}$ and Tauri Arumä $\mathrm{e}^{2,3}$
}

Lang, M., Arumäe, T. 2018. Assessment of forest thinning intensity using sparse point clouds from repeated airborne lidar measurements. - Forestry Studies | Metsanduslikud Uurimused 68, 40-50. ISSN 1406-9954. Journal homepage: http:// mi.emu.ee/forestry.studies

\begin{abstract}
Thinning cuttings create moderate disturbances in forest stands. Thinning intensity indicates the amount of felled wood relative to the initial standing volume. We used sparse point clouds from airborne lidar measurements carried out in 2008 and 2012 at Aegviidu test site, Estonia, to study stand level relationships of thinning intensity to the changes in canopy cover and ALS-based wood volume estimates. Thinning intensity $\left(K_{\mathrm{r}, \mathrm{HRV}}\right)$ was estimated from forest inventory data and harvester measurements of removed wood volume. The thinning intensity ranged from $17 \%$ to $56 \%$. By raising threshold from $1.3 \mathrm{~m}$ to $8.0 \mathrm{~m}$ over ground surface we observed less canopy cover change, but stronger correlation with thinning intensity. Correlation between ALS-based and harvester-based thinning intensity was moderate. The ALS-based thinning intensity estimate was systematically smaller than $K_{\mathrm{r}, \mathrm{HRV}}$. Forest height growth compensates for a small decrease in canopy cover and intensity estimates for weak thinnings are not reliable using sparse point clouds and a four-year measurement interval.
\end{abstract}

Keywords: forest management; canopy cover change; multitemporal laser scanning.

Author's addresses: ${ }^{1}$ Tartu Observatory, University of Tartu, 61602, Tõravere, Tartumaa, Estonia; ${ }^{2}$ Institute of Forestry and Rural Engineering, Estonian University of Life Sciences, Kreutzwaldi 5, Tartu 51006, Estonia; ${ }^{3}$ State Forest Management Centre, 10149, Toompuiestee 24, Tallinn; *e-mail: mait.lang@to.ee

\section{Introduction}

Forest disturbance monitoring is an important part of forest inventories. Disturbances like clear cuts or severe defoliation following insect attacks or forest fires can be detected from multi-temporal satellite images (Varjo \& Folving, 1995). Comparison of the expected spectral signature obtained from forest reflectance models or an analysis of scatterplots of spectral reflectance and forest age allow single image or remote sensing measurement-based change detection. Thinning cuttings do cause weak or moderate changes compared to the stand structure replacing disturbances like windbreaks or clearcutting. Maintenance fellings, including thinning cuttings, are used in forest management to regulate competition and give an advantage to the remaining trees.
In Estonia the area of thinning cuttings during 2008-2016 was between 24.6-48.6 thousand hectares per year and the mean felled volume was $72 \mathrm{~m}^{3} \mathrm{ha}^{-1}$, with both of the variables having a slight decreasing trend (Valgepea et al., 2017).

The effect of thinning cuttings on forest spectral signatures for the $10-30 \mathrm{~m}$ pixels (Uiga et al., 2003), a pixel size used also by the new Landsat- 8 Operational Land Imager (OLI) or Sentinel-2 MultiSpectral Instrument (MSI) scanners, is variable and depends on the amount of sunlit and shadowed objects in the scene visible to the sensor. Detection of weak thinnings where removal is less than $20 \%$ of basal area or wood volume is not reliable with spectral data (Olsson, 1994; Uiga et al., 2003). The effect of a thinning cutting is detectable usually no longer than $4-5$ years after the 
thinning event using the stand-level average spectral signature (Olsson, 1994). Compared to passive optical sensors on satellites, airborne laser scanning (ALS) has an advantage of recording exact coordinates of emitted pulse reflection locations (Large \& Heritage, 2009). This allows estimation of forest height (Kotivuori et al., 2016), canopy cover (CC) (Lang, 2010; Korhonen et al., 2011; Arumäe \& Lang, 2018) and live canopy base height (Arumäe \& Lang, 2013). Based on their strong correlation to canopy height and density the lidar point cloud metrics can also be used to estimate wood volume (Næsset, 1997; Lang et al., 2012). Repeated ALS measurements can be used to detect selective logging (Andersen et al., 2014) and to estimate forest height growth (Næsset \& Gobakken, 2005; Lang et al., 2017; Zhao et al., 2018). Assuming that the correlation between the ALS point cloud metrics with the wood volume is sufficiently strong, thinning intensity (i.e., relative volume of removed wood) could be estimated using ALS measurements carried out before and after the thinning. The Estonian Land Board has carried out ALS measurements as a part of topological survey and forest inventory on a yearly basis since 2008 (Maa-amet, 2017) to cover the entire of Estonia with four-year cycle. In this paper we use the sparse point clouds from the ALS measurements carried out in leaf-on conditions to estimate thinning intensity at forest stand level. Forest inventory (FI) data and harvester measurements of removed wood volume were used as insitu references.

\section{Material and Methods}

\section{Test site}

The site was established in 2008 (Anniste \& Viilup, 2010) and located in the northern part of Estonia, near Aegviidu (59 $19^{\prime} 20^{\prime \prime} \mathrm{N}$, $\left.25^{\circ} 35^{\prime} 36^{\prime \prime} \mathrm{E}\right)$. The terrain in Aegviidu is flat with occasional sand hills. The $15 \times 15 \mathrm{~km}$ area is mainly covered by hemiboreal co- niferous forests dominated by Scots pine (Pinus sylvestris L.) and Norway spruce (Picea abies (L.). Karst.). Birch (Betula pendula Roth and B. pubescens Ehrh.) and European aspen (Populus tremula L.) are less represented in the species composition or as stand dominant tree species. The dominating site types according to FI database and classification schema of Lõhmus (2004) are Myrtillus, Polytrichum-Myrtillus and Rodococcum. Most of the forests are typical of the hemiboreal region. Vertical structure is multi-layered with Norway spruce in the mid and lower layers.

\section{Airborne lidar data}

The Estonian Land Board carried out ALS measurements using a Leica ALS50-II (Leica, 2009) scanner (Table 1). The time between the two ALS measurements was four years. The measurements were part of routine aerial photography flights for forest inventory (Maa-amet, 2017) in the summer 2008 ALS $\left._{2008}\right)$ and in summer $2012\left(\mathrm{ALS}_{2012}\right)$. The point density for $\mathrm{ALS}_{2008}$ was $0.45 \mathrm{p} \mathrm{m}^{-2}$ and $0.25 \mathrm{p} \mathrm{m}^{-2}$ for $\mathrm{ALS}_{2012}$ data. The maximum scan angle from nadir was $28^{\circ}$.

The ALS data were processed using the FUSION freeware tools (McGaughey, 2014). Stand maps from the FI database were used to extract point clouds. The map geometries were buffered towards the inside by $10 \mathrm{~m}$ to decrease the influence of stand border errors. The ALS-based canopy cover $\left(C_{\text {ALS_1.3 }}\right)$ was calculated using a threshold (1.3 metres over the digital terrain model) method (Korhonen et al., 2011). All echoes were taken into account when calculating $C C_{\mathrm{ALS}}$ to avoid saturation that occurs in dense stands using only first returns in the case of sparse ALS point clouds (Arumäe \& Lang, 2018). To test the effect of forest understory on thinning intensity assessment $C_{\text {ALS_8.0 }}$ was calculated by raising the threshold to $8 \mathrm{~m}$ above the ground surface following the suggestion by Nijland et al. (2015). Point cloud height distributions 80-percentile $\left(H_{\mathrm{P} 80}\right)$ and 25-percentile $\left(H_{\mathrm{P} 25}\right)$ for the ALS-based wood volume estimation 
Table 1. Descriptive information for the ALS measurements. Data density unit is by points per square metre. Tabel 1. ALS mõõtmisandmete üldkirjeldus. Andmetiheduse ühik on punkti ruutmetri kohta.

\begin{tabular}{ccccc}
\hline Dataset / & $\begin{array}{c}\text { Flight year / } \\
\text { Andmestik }\end{array}$ & $\begin{array}{c}\text { Point density }\left(\mathrm{p} \mathrm{m}^{-2}\right) / \\
\text { Aasta }\end{array}$ & $\begin{array}{c}\text { Flight altitude }(\mathrm{m}) / \\
\text { Pennukôtihedus }\left(p \mathrm{~m}^{-2}\right)\end{array}$ & $\begin{array}{c}\text { Flight dates / } \\
\text { Kuupäevad }\end{array}$ \\
\hline $\mathrm{ALS}_{2008}$ & 2008 & 0.45 & 2,400 & $11.07,27.07,01.09$ \\
$\mathrm{ALS}_{2012}$ & 2012 & 0.25 & 3,800 & $20.06-04.07$ \\
\hline
\end{tabular}

(Lang et al., 2012; Arumäe \& Lang, 2016) were calculated excluding echoes with the height less than 1.3 metres above the digital terrain model (DTM).

\section{Forest inventory and management data}

The FI data with last updates made on 30.05.2007 were obtained from the database of Estonian State register for accounting of forest resource (IDB). The IDB contained the forest inventory data collected before the first ALS measurement. Data about commercial thinning operations were obtained from the Estonian State Forest Management Centre (RMK). The database included maps and final field inspection dates. The final field inspection may be carried out several months later than the actual end of the felling work. Available orthophotos were checked for additional control of the actual starting and ending times of the thinning operations. In this study we combined the RMK forest management maps and inventory data from the IDB to select sample stands. In the RMK forest management database the map objects of thinning cuttings may encompass several forest stands and the harvested wood volume is reported only for each group of thinned stands. For the analysis we selected only the map objects that overlapped on the latest stand map of IDB by at least $75 \%$ with a single forest stand. The stands smaller than 1 hectare or with less than 750 ALS pulse returns were excluded. For the analysis we selected the thinnings that were carried out in 2008-2012 according to forest management plans for the area including the Aegviidu test site.
The final sample dataset consisted of 153 thinned forest stands which belonged to 53 harvest map objects. Dominant species in the stands were Scots pine, birch or Norway spruce and black alder (Alnus glutinosa (L.) Gaertn.) among other species (Table 2). Similar selection filters were applied for the reference dataset of stands that were not thinned. Additionally, stands with $H_{\mathrm{P} 80}$ less than 5 metres in ALS $_{2012}$ were removed from the reference set as probable clear-cuts or partial clear-cuts. The final reference set was also dominated by Scots pine, followed by Norway spruce and birch stands (Table 2).

\section{Estimation of thinning intensity}

No measurements were made before and after the thinnings. For the estimation of the thinning intensity, FI variable values were updated with a growth model to year of the thinning operation to calculate standing volume before thinning $\left(V_{\mathrm{FI}}\right)$. Then the intensity of thinning (\%)

$K_{\mathrm{r}, \mathrm{HRV}}=100 \times V_{\mathrm{HRV}} / V_{\mathrm{FI}}$

was calculated using the removed wood volume measured by the harvester $\left(V_{\mathrm{HRV}}\right)$. For correcting the data to the thinning year we used an algebraic difference model of stand mean height $(H)$ and mean breast height diameter $(D)$ growth (Kangur et al., 2007) to update $H$ and $D$ to the year when the stand was thinned. The simulation was run using a one-year time step. The mortality of trees was assumed to be $0.3 \%$ per year. Sims et al. (2014) used database of Estonian Network of Forest Research Plots and es- 
Table 2. Descriptive information of sample forests in Aegviidu test site based on forest inventory database. Age $-A$, stand basal area $-G$, stand mean height $-\mathrm{H}$, site index $-\mathrm{H}_{100}$. Interquartile range is given in brackets.

Tabel 2. Puistute valimi üldkirjeldus. Vanus $-A$, rinnaspindala $-G$, keskmine kõrgus $-H$, bonitet $-H_{100}$. Sulgudes on kvartiilhälve.

\begin{tabular}{lccccc}
\hline \multirow{2}{*}{$\begin{array}{l}\text { Dominating species / } \\
\text { Enamuspuuliik }\end{array}$} & $\begin{array}{c}\text { Count/ } \\
\text { Arv }\end{array}$ & $\mathrm{A}(\mathrm{yrs})$ & $\mathrm{G}\left(\mathrm{m}^{2} \mathrm{ha}^{-1}\right)$ & $\mathrm{H}(\mathrm{m})$ & $\mathrm{H}_{100}(\mathrm{~m})$ \\
\hline Scots pine & 51 & $56(44-69)$ & $21.8(19-24)$ & $18.2(16-22)$ & $25.6(23-28)$ \\
Norway spruce & 40 & $40(37-44)$ & $19.8(18-21)$ & $16.7(14-19)$ & $30.3(28-33)$ \\
Birch & 49 & $40(33-45)$ & $16.1(14-19)$ & $15.4(13-19)$ & $25.8(24-28)$ \\
Other species & 5 & $49(43-57)$ & $18.6(17-20)$ & $18.0(16-21)$ & $25.8(25-27)$ \\
\hline & 1,100 & $85(55-105)$ & $19.4(17-23)$ & $15.1(12-19)$ & $18.3(17-21)$ \\
Scots pine & 466 & $56(29-90)$ & $14.1(11-22)$ & $12.9(7-22)$ & $22.4(21-25)$ \\
Norway spruce & 405 & $51(23-73)$ & $14.4(7-21)$ & $14.3(5-20)$ & $21.8(17-25)$ \\
Birch & 142 & $48(38-61)$ & $20.7(17-24)$ & $15.8(15-20)$ & $24.2(21-25)$ \\
Other species & \multicolumn{5}{c}{ Reference stands / Harvendamata võrdluspuistud } \\
\hline
\end{tabular}

timated tree mortality for 5 -year period as $3.4 \%$ on recently managed plots and $8.0 \%$ on low intensity/unmanaged forests. However, the sample of forests used by Sims et al. (2014) contained old stands with a higher mortality rate. To avoid unrealistically dense forests with respect to mean tree size in our calculations, Nilson's model of forest stand sparsity at the self-thinning $\left(L_{\mathrm{TJ}}\right)$ state

$L_{\mathrm{TJ}}=k_{1}+k_{2} \times D+k_{3} \times D \times H_{100}+k_{4} \times H_{100}$

taken from Sims et al. (2009), was used as an additional constraint in our forest growth simulation; where $H_{100}$ is the site fertility index $(\mathrm{m})$ and $k_{\mathrm{x}}$ are species specific parameters. In the forest growth simulations we used stand sparsity denoted by $L$

$\mathrm{L}=\frac{100}{\sqrt{N}}$

where $N$ is the stand density (trees ha-1), $L$ was kept greater than the $L_{\mathrm{TJ}}$ by adjusting $N$ to increase mortality due to selfthinning. Finally, standing wood volume was calculated as $V_{\mathrm{FI}}=G \times H \times F$ where $G$ is stand basal area $\left(\mathrm{m}^{2} \mathrm{ha}^{-1}\right), H$ is the forest height (m) and $F$ is the form factor. $H \times F$ was calculated with a common model used in Estonia (Metsakorraldus, 2015) based on $H$.

The second estimate of thinning intensity was calculated from the multi-temporal ALS data by using the wood volume model

$V_{\mathrm{ALS}}=\left(2.1 \times H_{\mathrm{P} 80}{ }^{1.71}+3.99 \times H_{\mathrm{P} 25}\right) \times \mathrm{CC}_{\mathrm{ALS}}{ }^{0.91}$,

published by Arumäe \& Lang (2016). Lidarbased thinning intensity (\%) was calculated as

$K_{\mathrm{r}, \mathrm{ALS}}=100 \times\left(V_{\mathrm{ALS} 2008}-V_{\mathrm{ALS} 2012}\right) / V_{\mathrm{ALS} 2008}$

\section{Results}

The change in $\mathrm{CC}_{\mathrm{ALS} \_1.3}$ showed a weak linear correlation with the FI and harvested stem volume based thinning intensity $K_{\mathrm{r}, \mathrm{HRV}}\left(R^{2}=0.2, p\right.$-value $<0.01$; Figure 1$)$. The gain of the fitted linear model was only 0.34 indicating that the increase in thinning intensity does not necessarily increase loss 
of canopy cover. The weak correlation was most likely because thinning intensity was calculated based on removed wood volume, measured by the harvesters, whereas the $C C_{\mathrm{ALS} 1.3}$ change is based on canopy changes. The $C C_{\text {ALS_1.3 }}$ itself has only a weak correlation with FI based standing wood volume estimates $(r=0.18, p$-value $<0.01)$. We note here that the FI based wood volume is known to be slightly underestimated (Arumäe \& Lang, 2016) compared to measured wood volumes based on sample plots. There also may be random errors in the database. Therefore the thinning intensity based on removed wood volume $V_{\mathrm{HRV}}$ and standing wood volume $V_{\mathrm{FI}}$ might be overestimated, as the thinning intensities stronger than $50 \%$ are not that common in practice. Additional errors may be related to the models used for growing the standing wood volume to the year of thinning, however, these errors can be assumed rather small compared to the errors of initial forest inventory records. Some errors of estimating $C C_{\mathrm{ALS}}$ are caused by using low density ALS data. However, the $C_{\text {ALS_1.3 }}$ change over four years was significantly higher for thinned stands (Figure 1) compared to the $C C_{\mathrm{ALS} \_1.3}$ of reference stands $(p$-value $<0.01)$.

Raising the canopy cover estimation threshold from $1.3 \mathrm{~m}$ to $8.0 \mathrm{~m}$ over ground surface increased the correlation between the change in canopy cover and thinning intensity $K_{\mathrm{r} \text { HRV }}\left(R^{2}=0.34\right.$, pvalue $<0.01$; Figure 2). The slope of the linear model increased to 0.42 indicating that $C C_{\text {ALS_8.0 }}$ may be better lidar metric for thinning intensity estimation than $\mathrm{CC}_{\mathrm{ALS} \text { _1.3. }}$. However, the average decrease of $C C_{\text {ALS_8.0 }}(14.6 \%)$ was significantly ( $p$-value $<0.01)$ smaller than the decrease of $C_{\text {ALS_1.3 }}(21.9 \%)$.

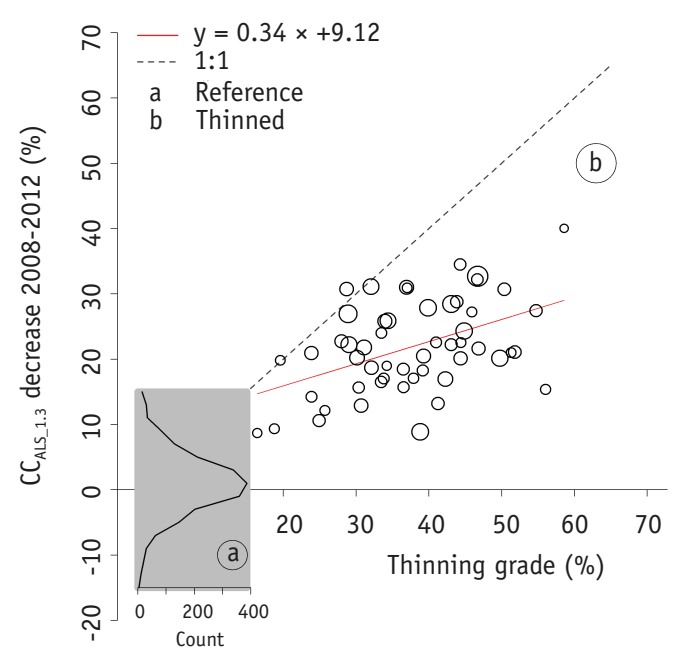

Figure 1. Distributions of airborne laser scanningbased canopy cover $\left(\mathrm{CC}_{\mathrm{ALS}-1.3}\right)$ change at $1.3 \mathrm{~m}$ threshold level in reference stands (a). Relationship of thinning intensity and $\mathrm{CC}_{\mathrm{ALS} 1.3}(\mathrm{~b})$. Symbol size is dependent on sample area.

Joonis 1. Harvendamata puistute 1,3 m kõrgusnivool arvutatud katvuse $\left(\mathrm{CC}_{\text {ALS_1.3 }}\right)$ muutuse jaotus (a). Raiekraadi ja $C_{\text {ALS_1.3 }}$ muutuse $\operatorname{seos}(b)$.

For two samples with the smallest thinning intensity the decrease in $\mathrm{CC}_{\mathrm{ALS} \_8.0}$ was negative meaning that the ALS-based canopy cover estimate was greater for the after thinning state. Many trees in these stands were just less than 8 metres high in 2008 and the height increment of their crown surface increased the stand $C_{\text {ALS_8.0 }}$ more than was decreased by the thinning cutting.

In reference stands the stem volume increased on average by $10 \%$ (interquartile range $5.0 \%$ to $17.7 \%$ ) when $V_{\mathrm{ALS}}$ from $\mathrm{ALS}_{2008}$ and $\mathrm{ALS}_{2012}$ was compared. In the thinned stands standing wood volume estimates based on ALS data decreased as expected (Figure 3) in most of the stands. The average thinning intensity $K_{\mathrm{r} \text {, ALS }}$ according to the $V_{\mathrm{ALS}}$ change was $19.5 \%$ (interquartile range $9.6 \%$ to $27.3 \%$ ). This was systematically smaller than the harvester measurements-based $K_{\mathrm{r} \text {, HRV }}$. The slope of a linear regression model of $K_{\mathrm{r}, \mathrm{HRV}}$ and $K_{\mathrm{r} \text {, ALS }}$ (dependent variable) was 


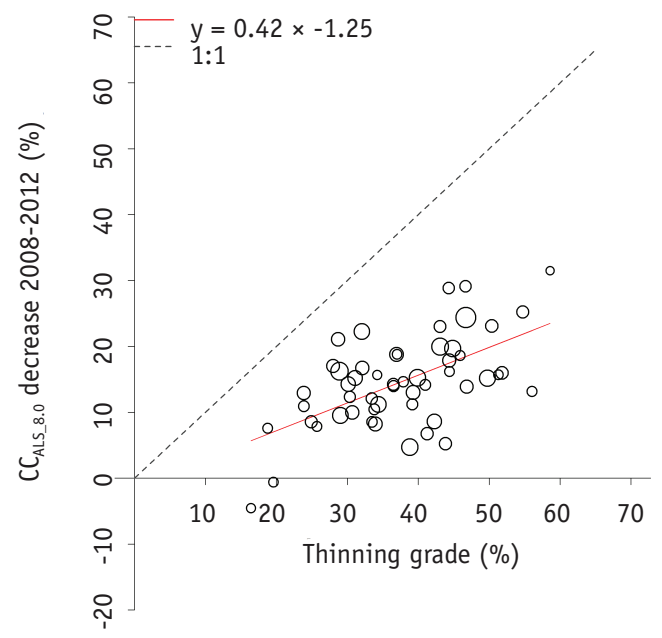

Figure 2. Relationship of thinning intensity with canopy cover $\left(\mathrm{CC}_{\text {AL__8.0 }}\right)$ decrease at $8.0 \mathrm{~m}$ level.

Joonis 2. Raiekraadi seos 8,0 m kõrgusnivool arvutatud katvuse (CC $C_{\text {AL__. } 8.0)}$ muutusega.

0.5 , determination coefficient was 0.26 and residual standard error was $8.0 K_{\mathrm{r} \text {, ALs }}$ units with 51 degrees of freedom. Interpretation of the results in some stands where $K_{\mathrm{r} \text {, ALS }}$ was close to zero or negative can be given with the $V_{\mathrm{ALS}}$ model equation (4). The model main arguments are point cloud height percentiles and the result is corrected for canopy cover. From Figure (1) we saw that the canopy cover $\mathrm{CC}_{\mathrm{ALS} \_1.3}$ decreased for all samples. This indicates that there must be a compensating increase in point cloud height distribution percentiles that eliminate the decrease in canopy cover in the $V_{\text {ALS }}$ model. By using the $V_{\text {ALS }}$ model (4) we can easily calculate for a stand that has initial $H_{\mathrm{P} 80}=20 \mathrm{~m}$ and $H_{\mathrm{P} 25}=5 \mathrm{~m}$ that with a decrease of 0.8-0.7 = 0.1 units in canopy cover, the $K_{\mathrm{r}, \mathrm{ALS}}=0$ if $H_{\mathrm{P} 80}$ increases by $1.6 \mathrm{~m}$. In a real situation this increase in $H_{\mathrm{P} 80}$ for the stand can be the combined result of stand height growth during four years, influence of view geometry, scanner settings and/or flight parameters.

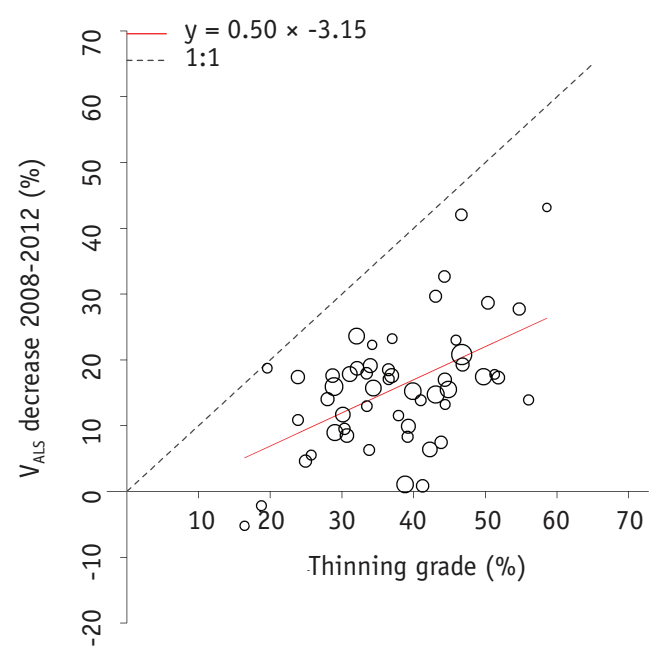

Figure 3. Comparison of thinning intensity to the relative change of wood volume estimate based on airborne lidar data.

Joonis 3. Hõredast punktipilvest enne ja peale harvendusraiet hinnatud tüvemahu suhtelise muutuse seos raiekraadiga.

\section{Discussion}

The average height increment in young forests ( $<20$ years) in Estonia is about $0.5 \mathrm{~m}$ per year depending on soil fertility (Kängsepp et al., 2015). For older forests, the height increment is usually smaller $(0.3 \mathrm{~m}$ per year) depending also on soil fertility and forest age (Metslaid et al., 2011). Over four years, i.e. the time between regular survey flights, a forest height increment in the range of 1 to 2 metres can be expected in Estonia depending on the forest age and site fertility. At the same time, a small increase in canopy cover can be expected in younger stands during the intensive growth phase and a marginal decrease may occur in older stands due to natural mortality if there are no disturbances. The estimated canopy cover value from repeated ALS measurements, however, varied up to $\pm 13 \%$ in the reference stands where no thinnings were carried out and no other substantial disturbances were recorded. A possible variation source is the 
automatic gain control (Vain et al., 2010) of the Leica ALS50-II scanner, which regulates the emitted pulse energy and therefore has an influence to the number of returns per pulse. Canopy cover estimates do increase with scanning angle (Disney et al., 2010; Korhonen et al., 2011; Arumäe \& Lang, 2018). As the flights were carried out at different heights, the pulse footprint size may have had an influence on the $C_{\mathrm{ALS}}$ estimates (Keränen et al., 2016). Disney et al. (2010) carried out simulation experiments and found that an increase in footprint size caused a small increase in the mean height of first returns from the forest canopy. However, Disney et al. (2010) summarized also results from published empirical studies and concluded that the influence of the increment in footprint size on pulse return heights depends on the pulse energy per unit area. In our data the AGC of the Leica ALS50-II controlled the pulse energy and the difference in footprint size was probably eliminated. Forest growth combined with the estimation errors of forest height and canopy cover set a limit to the detection and interpretation of low intensity thinnings using sparse ALS point clouds.

The correlation was weak between the $C C_{\mathrm{ALS}}$ change and thinning intensity calculated using harvester measurements based wood removal. The weak correlation was likely related to the fact that $C C_{\mathrm{ALS}}$ is not directly correlated to measured wood volume in the hemiboreal forests in Estonia (Lang et al., 2014). On the one hand, our estimates of the thinning intensity were based on harvester measurements of removed wood volume and forest management inventory data, updated with a growth model, and not on re-measured sample plots. On the other hand, the small sample plots (radius of 7 to $15 \mathrm{~m}$ ) usually established in forest inventories would probably be insufficient for stable mean values of $C C_{\mathrm{ALS}}$ when sparse point clouds are used. Arumäe \& Lang (2018) found that up to $8 \%$ differences can occur in $C C_{\text {ALS }}$ in sample plots solely when data from different flight paths are used. A part of the scatter in the thinning intensity and $C C_{A L S}$ relationship was therefore caused by the $C C_{\mathrm{ALS}}$ estimation error that was apparent also in the comparison of the CC of the reference stands. Additional mismatch in the thinning intensity and $C C_{\mathrm{ALS}}$ relationship can be caused by errors in FI database wood volume estimates, which are known to be underestimated (Arumäe \& Lang, 2016) compared to sample plot measurements. In harvester measurements, on the other hand, precise stem volume measure of all trees during the felling operation is recorded. However, harvesters frequently do not process the crown part of deciduous trees due to large branches and some unrecorded stem volume remains in the tree tops that are left as residues for biodiversity and soil stability under machines.

The experiment with reference level raised from $1.3 \mathrm{~m}$ to $8.0 \mathrm{~m}$ showed that canopy cover change decreased and the relationship with thinning intensity became stronger. This follows from the removal of forest understory for practical and safety reasons during the thinning cutting operations. The effect indicates also that thinnings in the sample stands are carried out by cutting smaller and suppressed trees. The drawback of using higher reference level was that in some stands the decrease in $C_{\text {ALS 8.0 }}$ was so small that ALS-based detection of the thinning event would be questionable from the multi-temporal sparse point clouds. However, the detection can be based on $C_{\text {ALS_1.3, which had greater }}$ change after thinning.

While canopy cover change is a simple variable for the detection of thinning cuttings, the change in stand volume is a more important quantity for carbon reporting and thinning intensity is a commonly used variable in describing forest management practice. We applied a wood volume estimation model to multi-temporal point clouds and found that the thinning intensity estimate $K_{r \text {, ALS }}$ was moderately correlated with thinning intensity based on harvester measurements $K_{\mathrm{r}, \mathrm{HRV}}$. We found that scat- 
ter in this relationship is caused in addition to the errors in $K_{\mathrm{r} \text {, HRV }}$ by the forest height growth during the time between repeated ALS measurements, errors in the canopy cover estimation and also by the influence of scanner settings. A small decrease in canopy cover after low intensity thinning cutting can be fully compensated by the forest height growth during four years and the difference of point cloud based estimates of wood volume is not statistically significant. This sets a lower limit to the estimation of amount of harvested wood volume using sparse ALS point clouds, while the detection of the thinning occurrences may still be possible based on change in canopy cover.

\section{Conclusions}

The following conclusions can be drawn based on our study with the metrics calculated from sparse point clouds representing individual stands. Sparse point clouds from repeated measurements of routine, large area airborne laser scanning can be used to estimate thinning intensity of thinning cuttings where more than $20 \%$ of the volume is removed and the changes have sufficiently strong influence on canopy cover. Canopy cover changes at $8.0 \mathrm{~m}$ reference level are systematically smaller than at $1.3 \mathrm{~m}$ reference level over ground surface, but have a stronger correlation with the thinning intensity because of the elimination of the contribution of the forest understorey. Forest height growth during four years between the ALS measurements compensated for small changes in canopy cover and the estimation of thinning intensity or the amount of removed wood volume was not reliable for low intensity thinning cuttings.

Acknowledgements. The authors would like to thank the Estonian Land Board for the airborne lidar data. The harvester measurement data was kindly given for the analysis by the Estonian State Forest Management Centre. Dr. John Stanturf commented the manuscript and edited the English language. We thank anonymous reviewers for comments that helped us to improve the quality of the manuscript. Data analysis was supported by the Ministry of Education and Research grant IUT21-4.

\section{References}

Andersen, H.-E., Reutebuch, S.E., McGaughey, R.J., d'Oliveira, M.V.N., Keller, M. 2014. Monitoring selective logging in western Amazonia with repeat lidar flights. - Remote Sensing of Environment, 151, 157-165.

Anniste, T., Viilup, Ü. 2010. Estimation of forest characteristics with laser scanning. (Metsa takseertunnuste määramisest laserskanneerimise abil). Articles and Studies, Luua Forestry College, 10, 38-53. (In Estonian).

Arumäe, T., Lang, M. 2013. A simple model to estimate forest canopy base height from airborne lidar data. Forestry Studies / Metsanduslikud Uurimused, $58,46-56$

Arumäe, T., Lang, M. 2016. ALS-based wood volume models of forest stands and comparison with forest inventory data. - Forestry Studies / Metsanduslikud Uurimused, 64, 5-16.

Arumäe, T., Lang, M. 2018. Estimation of canopy cover in dense mixed species forests using airborne lidar data. - European Journal of Remote Sensing, 51(1), 132-141.

Disney, M.I., Kalogirou, V., Lewis, P., Prieto-Blanco, A., Hancock, S., Pfeifer, M. 2010. Simulating the impact of discrete-return lidar system and survey characteristics over young conifer and broadleaf forests. - Remote Sensing of Environment, 114, 1546-1560.

Kängsepp, V., Kangur, A., Kiviste, A. 2015. Tree height distribution dynamics in young naturally regenerated study plots. - Forestry Studies / Metsanduslikud Uurimused, 63, 100-110.

Kangur, A., Sims, A., Jõgiste, K., Kiviste, A., Korjus, H., Gadow, K.v. 2007. Comparative modeling of stand development in Scots pine dominated forests in Estonia. - Forest Ecology and Management, 250(1-2), 109-118.

Keränen, J., Maltamo, M., Packalen, P. 2016. Effect of flying altitude, scanning angle and scanning mode on the accuracy of ALS based forest inventory. International Journal of Applied Earth Observation and Geoinformation, 52, 349-360.

Korhonen, L., Korpela, I., Heiskanen, J., Maltamo, M. 2011. Airborne discrete-return LIDAR data in the estimation of vertical canopy cover, angular canopy closure and leaf area index. - Remote Sensing of Environment, 115, 1065-1080.

Kotivuori, E., Korhonen, L., Packalen, P. 2016. Nationwide airborne laser scanning based models 
for volume, biomass and dominant height in Finland. - Silva Fennica, 50(4), 1-28, article id 1567. http:/ / dx.doi.org/10.14214/sf.1567

Lang, M. 2010. Estimation of crown and canopy cover from airborne lidar data. - Forestry Studies / Metsanduslikud Uurimused, 52, 5-17.

Lang, M., Arumäe, T., Anniste, J. 2012. Estimation of main forest inventory variables from spectral and airborne lidar data in Aegviidu test site, Estonia. Forestry Studies / Metsanduslikud Uurimused, 56, 27-41.

Lang, M., Arumäe, T., Laarmann, D., Kiviste, A. 2017. Estimation of change in forest height growth. Forestry Studies / Metsanduslikud Uurimused, 67, 5-16.

Lang, M., Arumäe, T., Lükk, T., Sims, A. 2014. Estimation of standing wood volume and species composition in managed nemoral multi-layer mixed forests by using nearest neighbour classifier, multispectral satellite images and airborne lidar data. Forestry Studies / Metsanduslikud Uurimused, 61, 47-68.

Large, A.R.G., Heritage, G.L. 2009. Laser scanning evolution of the discipline. - Heritage, G.L., Large, A.R.G (eds.). Laser scanning for the environmental sciences. Chichester, West Sussex, John Wiley \& Sons Ltd, 1-20.

Leica. 2009. Leica ALS50-II airborne laser scanner product specifi cations. Leica Geosystems AG Heerbrugg, Switzerland.

Lõhmus, E. 2004. Forest site types in Estonia. (Eesti metsakasvukohatüübid). Loodusfoto, Tartu, Estonia. 80 pp. (In Estonian).

Maa-amet. 2017. Orthophoto metadata by year. (Ortofotod aastate ja objektide kaupa). [WWW document]. - URL http://geoportaal.maaamet.ee/ est/Andmed-ja-kaardid/Ortofotod/Ortofotodaastate-ja-objektide-kaupa-p27.html [Accessed 6 June 2017]. (In Estonian).

McGaughey, R.J. 2014. FUSION/LDV: Software for LIDAR Data Analysis and Visualization. March 2010 - FUSION, Version 3.42. United States Department of Agriculture Forest Service Pacific Northwest Research Station. 211 pp.

Metsakorraldus. 2015. Forest management act. (Metsa korraldamise juhend). - Riigi Teataja, RT I, 24.11.2015, 6. (In Estonian).

Metslaid, S., Sims, A., Kangur, A., Hordo, M., Jõgiste, K., Kiviste, A., Pertti, H. 2011. Growth patterns from different forest generations of Scots pine in Estonia. - Journal of Forest Research, 16, 237-243.

Næsset, E. 1997. Estimating timber volume of forest stands using airborne laser scanner data. - Remote Sensing of Environment, 61, 246-253.

Næsset, E., Gobakken, T. 2005. Estimating forest growth using canopy metrics derived from airborne laser scanner data. - Remote Sensing of Environment, 96, 453-465.

Nijland, W., Coops, N.C., Macdonald, S.E., Nielsen, S.E., Bater, C.W., Stadt, J.J. 2015. Comparing patterns in forest stand structure following variable harvests using airborne laser scanning data. - Forest Ecology and Management, 354, 272-280.

Olsson, H. 1994. Changes in satellite-measured reflectances caused by thinning cuttings in boreal forest. - Remote Sensing of Environment, 50, 221-230.

Sims, A., Kiviste, A., Hordo, M., Laarmann, D., Gadow, K.v. 2009. Estimating tree survival: a study based on the Estonian Forest Research Plots Network. - Annales Botanici Fennici, 46, 336-352.

Sims, A., Mändma, R., Laarmann, D., Korjus, H. 2014. Assessment of tree mortality on the Estonian Network of Forest Research Plots. - Forestry Studies / Metsanduslikud Uurimused, 60, 57-68.

Uiga, R., Lang, M., Lükk, T., Anniste, J. 2003. Mapping the location of forest cuttings using Landsat 5 TM and Landsat 7 ETM+ imagery. - Kiviste, K., Lember, S., Kivastik, S. (eds.). Postgraduate research papers at the Faculty of Forestry. Transactions of the Faculty of Forestry, Estonian Agricultural University,Tartu, Trükipunkt, 36, 142-161.

Vain, A., Yu, W., Kaasalainen, S., Hyyppä, J. 2010. Correcting airborne laser scanning intensity data for automatic gain control effect. - IEEE Geoscience and Remote Sensing Letters, 7, 511-514.

Valgepea, M., Sims, A., Raudsaar, M., Timmusk, T. 2017. Fellings. - Raudsaar, M., Siimon, K-L., Valgepea, M. (eds.). - Yearbook Forest 2017. Tallinn, Keskkonnaagentuur, 3, 5-36.

Varjo, J., Folving, S. 1995. Monitoring of forest changes using unsupervised methods: a case study from boreal forest on mineral soils. - Scandinavian Journal of Forest Research, 12, 362-369.

Zhao, K., Suarez, J.C., Garcia, M., Hu, T., Wang, C., Londo, A. 2018. Utility of multitemporal lidar for forest and carbon monitoring: Tree growth, biomass dynamics, and carbon flux. - Remote Sensing of Environment, 204, 883-897. 


\title{
Puistute harvendusraie kraadi hindamine väikese tihedusega lennukildari andmete põhjal
}

\author{
Mait Lang ja Tauri Arumäe
}

\section{Kokkuvõte}

Harvendusraietega reguleeritakse puistutes puudevahelist konkurentsi, kujundatakse liigilist koosseisu ja valitakse välja tulevikupuud. Harvendusraiete pindala Eestis on aastati ajavahemikus 2008-2016 olnud 24,6-48,6 tuhat hektarit ja keskmine väljaraie $72 \mathrm{~m}^{3} \mathrm{ha}^{-1}$ ning mõlema tunnuse puhul on märgata kahanemistrendi (Valgepea et al., 2017). Harvendusraiete monitooring on üks metsaseire osa. Keskmise ruumilahutusega multispektraalsete satelliidipiltide abil on võimalik tuvastada suurema suhtelise väljaraiega harvendusi (Olsson, 1994), kuigi puistu harvendamise mõjul võib individuaalse 10-30 m küljepikkusega piksli spektraalne heledus nii kahaneda kui kasvada (Uiga et al., 2003) sõltuvalt nähtavate objektide peegeldustegurist ning varjude hulgast. Lennukilt tehtud laserskaneerimise (ALS) tulemusena saadud kolmemõõtmelised punktiparved kajastavad üsna hästi metsa struktuuri ja võimaldavad hinnata metsa kõrgust, võrastiku tihedust ja nende põhjal ka rinnaspindala ning tüvemahtu (Næsset, 1997; Lang et al., 2012; Kotivuori et al., 2016). Eestis on lidar olnud alates 2008. aastast Maa-ametis kasutusel nii topograafilise kaardistuse kui ka metsakorralduse tarbeks tehtavatel lendudel lisaks multispektraalsele kaamerale (Maa-amet, 2017).

Käesoleva töö eesmärgiks oli uurida võimalusi harvendusraietel puistu tasemel väljaraiutava puidu suhtelise mahu ehk raiekraadi hindamiseks kasutades Maaameti poolt tehtud ALS mõõtmiste andmeid 2008. ja 2012. aastast (tabel 1) Aegviidu lähedal asuval testalal (Anniste \& Viilup, 2010; Lang et al., 2012), kus on domineerivad okaspuupuistud (tabel 2). ALS andmetelt arvutati igale puistule kõikidel peegeldustel põhinev katvus (Lang,
2010) $1,3 \mathrm{~m}\left(\mathrm{CC}_{\mathrm{ALS} \_1.3}\right)$ ja $8,0 \mathrm{~m}\left(\mathrm{CC}_{\mathrm{ALS} \_8.0}\right)$ referentsnivool, punktiparve kõrgusjaotuse 80 -protsentiil $\left(H_{\mathrm{P} 80}\right)$ ja alumine kvartiil $\left(H_{\mathrm{P} 25}\right)$ ning lõpuks ka tüvemahu muutusel põhinev raiekraad $K_{r \text {, ALS }}(4,5)$. Maapealse referentsina kasutati Metsaregistri andmebaasist (30.05.2007) saadud tüvemahu ja harvestermõõtmistel registreeritud tüvemahu järgi hinnatud raiekraadi $K_{r, H R V}(1)$. Takseerandmed korrigeeriti igas testpuistus harvendusraie aastasse kasvatades algebralise diferentsmudeliga (Kangur et al., 2007) puistu kõrgust ning rinnasläbimõõtu ja kahandades puude arvu arvestades keskmist surevust ning lisaks ka puistute piirtiheduse mudelit $(2,3)$. Keskmise surevuse määraks võeti $0,3 \%$ aastas, mis on veidi väiksem kui äsja harvendatud või harvendusraieeast vanemates puistutes (Sims et al., 2014). Vajadusel korrigeeriti puude arvu $N$ veelgi, kui puistu hõredus L (3) muutus piirtihedusest (2) väiksemaks.

Tulemustest selgus, et raiekraadi $K_{\mathrm{r}, \mathrm{HRV}}$ ja $C C_{\text {ALS_1.3 }}$ korrelatsioon on nõrk (joonis 1 ), samas aga on $\mathrm{CC}_{\mathrm{ALS} \_1.3}$ muutus usaldusväärselt harvendusraiealadel suurem kui kontrollpuistutes ( $p$-väärtus $<0,01)$. Alusmetsa ja madalamate puude mõju välistav maapinnast kõrgemal nivool arvutatud $\mathrm{CC}_{\mathrm{ALS} \text { _8.0 }}$ muutus vähem, aga oli veidi tugevamalt korreleeritud raiekraadiga (joonis 2). Sellist kahel erineval kõrgusnivool arvutatud katvuse muutust saab seostada alameetodil harvendamisega. Enne ja peale raiet tehtud lasermõõtmiste põhjal arvutatud puistu tüvamahu suhtelise kahanemise hinnang $K_{\mathrm{r} \text {, ALs }}$ oli keskmiselt 19,5\% (kvartiilhälve 9,6\%-27,3\%). Sama aja jooksul kontrollpuistute tüvemaht $V_{\text {ALS }}$ arvutatuna mudeliga (4) kasvas keskmiselt 10\%. ALS-põhine raiekraad $K_{r \text {, ALS }}$ oli harvestermõõtmistel 
põhineva raiekraadiga $K_{\mathrm{r}, \text { HRV }}$ keskmiselt (determinatsioonikordaja $R^{2}=0,26$ ) korreleeritud (joonis 3). Mõnes puistus oli $K_{\mathrm{r} \text {, ALS }}$ nullilähedane või isegi negatiivne. Seda ilmingut selgitab $V_{\text {ALS }}$ mudeli (4) kuju, kus tüvemahu hindamisel aluseks võetava võrastiku katvuse kahanemise võib kompenseerida punktipilve kõrgusjaotuse protsentiilide kasv. Tuleb arvestada, et nii katvuse kui ka kõrgusjaotuse protsentiilide hinnangutes esineb väikseid juhuslikke ning arvatavasti ka süstemaatilisi vigu. Eksperimendid ALS andmetele tugineva tüvemahu mudeliga (4) näitasid, et neljaaastase kordusmõõtmiste perioodi jooksul kompenseerib näiteks 1,6 m suurune $H_{\mathrm{P} 80}$ kõrguse kasv nõrgema harvendusraie põhjustatud kahanemise $0,8-0,7=0,1$ võ-

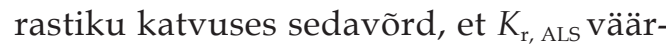
tus tuleb null, kui algne $H_{\mathrm{P} 80}=20 \mathrm{~m}, H_{\mathrm{P} 25}=$ $5 \mathrm{~m}$. Selline $H_{\mathrm{P} 80}$ kasv sisaldab nii tegelikku metsa kõrguse kasvu kui ka hinnangutes esineda võivaid nihkeid. Kokkuvõtteks järeldati, et hõredate punktipilvede põhjal ei ole usaldusväärselt võimalik alla 20\%-lise raiekraadi korral väljaraiutud tüvemahtu hinnata, kui kasutada puistu piiride järgi lõigatud punktipilvede keskmisi meetrikuid. Harvendusraiete tuvastamiseks sobib pigem madalamal võrdlusnivool arvutatav $\mathrm{CC}_{\mathrm{ALS} 1.3}$ kui $C C_{\mathrm{ALS} \text { 8.0. }}$. Aerolidarmõõdistusel saadud hõredate punktipilvede info paremaks kasutamiseks metsade seirel tuleks edaspidi uurida ühe puistu piiresse jäävaid peegeldusi väiksemate alamhulkade (segmentide) kaupa. 